\title{
Appraisal of Key Abiotic Parameters Affecting Street Tree Growth
}

\author{
Pierre Jutras, Shiv O. Prasher, and Guy R. Mehuys
}

\begin{abstract}
Street trees must cope with severe environmental conditions. Identification of factors that modulate their survival and growth is a key process for successful management. To estimate these factors, contingency analyses were carried out using abiotic data collected locally for Norway maple (Acer platanoides L.), silver maple (Acer saccharinum L.), hackberry (Celtis occidentalis L.), green ash (Fraxinus pennsylvanica Marsh.), honeylocust (Gleditsia triacanthos L.), littleleaf linden (Tilia cordata Mill.), and Siberian elm (Ulmus pumila L.) trees. Also, comparable analyses were performed on a merged all-species data set. Whereas sharp differential growth was found between commercial zones and residential areas, studied species demonstrated ecological tolerance as individuals were found normally or vigorously growing in severe conditions. In this situation, ample irradiation intensity might be an important factor contributing to urban tree growth. Statistical analyses led to the identification of a threshold level (80\% of total potential irradiation) above which optimal growth was found in commercial zones. Research results also brought out the importance of the underlying surficial deposits: slow growth rates were linked to the presence of sand/gravel deposits. Finally, higher soil de-icing salt concentrations were found in tree pits where trees were transplanted closer to the curb and on wider streets.

Key Words. Compaction; Contingency Analysis; De-icing Salt Effect; Light Irradiation; Street Trees; Surficial Deposit; Urban Zone Type.
\end{abstract}

Trees provide a basic contact with nature, heighten pleasure in our surroundings, and directly improve human health and the quality of life (Lohr et al. 2004). They soften architectural lines and accentuate structural details, relieve the monotony of pavement and masonry, make enticing play areas, and unify and give coherence to visually chaotic scenes (Gorman 2004). In retail districts, visitors perceive the streetscape canopy to be an integral amenity of the city's shopping environment and well-planned canopy-covered streets are highly appreciated (Wolf 2004). Yet, urban landscapes are environmentally detrimental to the biology of trees (Percival 2005). During summer months, high ambient temperatures may trigger water deficits and exceed the optimum range for photosynthesis (DeGaetano and Hudson 2000). Soil water resources in the street planting pits are generally reduced during this period as well (Nielsen et al. 2007). Severe physiological problems then develop: impaired respiration, protein synthesis, secondary carbohydrate metabolism, disintegration of leaf structure, and reduced growth of stems and twigs, followed by death of terminal buds and branches and by production of small and chlorotic leaves (Kozlowski and Pallardy 1997). Additionally, temperatures exceeding $30^{\circ} \mathrm{C}\left(86^{\circ} \mathrm{F}\right)$ in root zones at planting sites are not uncommon and may exceed $40^{\circ} \mathrm{C}\left(104^{\circ} \mathrm{F}\right)$ (Celestian and Martin 2004). Freezing temperatures have also been identified as a major detrimental condition (Collins et al. 2000). Spring and autumn frosts may injure trees and induce frost cracks or sunscald on stems (Harris et al. 1999). Low soil temperature inhibits both root initiation and growth of existing roots, decreases absorption of water by increasing the resistance to water movement across living root cells, and reduces both passive and active uptake of minerals (Kozlowski and Pallardy 1997).
Urban soil conditions may also be adverse for adequate tree development. Common conditions are deficiency in nutrients (De Kimpe and Morel 2000); compaction in and around tree pits and construction sites which lowers soil aeration and water movement and impairs root growth (Smith et al. 2001; Percival et al. 2004); restricted water drainage and water-holding capacity; interrupted organic matter and nutrient cycling; modified soil organism activity; significant concentration levels of heavy metals (Lu et al. 2003); and modified soil reactions consequential to use of de-icing salts (Zimmerman et al. 2005). Indeed, during winter, large volumes of de-icing salts are applied in some cities. Total de-icing salt use in cold climates has been rising since 1970 due to increasing urbanization, roadway construction, and public safety concerns (Paludan-Miller et al. 2002; Percival and Fraser 2007). High salt concentration induces iron and potassium chlorosis (Lemaire and Rossignol 1999), and severe dehydration of leaves that closes stomata and reduces photosynthesis (Zimmerman and Jull 2006). It is one of the most serious causes of streettree stress (Cekstere et al. 2008).

Frequently, trees are confronted with insufficient irradiation levels. Certain downtown environments are known as urban canyons because the shade patterns cast by buildings are somewhat analogous to the shade cast by canyon walls (Harris and Bassuk 1993). These shady urban sites can impose severe stress on trees. Low light intensity levels bring in leaf necrosis and significant root growth reduction (Kjelgren 1995). Additionally, trees are adversely affected by a wide variety of environmental pollutants. The most important are sulfur dioxide $\left(\mathrm{SO}_{2}\right)$, ozone $\left(\mathrm{O}_{3}\right)$, fluorides $(\mathrm{F})$, oxides of nitrogen ( $\mathrm{NO}$ ), and particulates (Garrec 1999). Pollutants not only injure trees but influence their metabo- 
lism and reduce their growth without causing visible injury. By weakening trees, air pollutants often predispose them to certain diseases (Kozlowski 1986). Finally, there is a growing list of exotic insects and pathogens that are current or looming threats to community forests throughout North America (Ball et al. 2007).

Trees facing these arrays of man-made and natural stresses may have reduced life spans compared to trees in rural areas or natural habitats (Cregg and Dix 2001). Although estimates vary, life spans of trees in downtown urban areas are often less than 15 years (Nowak et al. 1990). Understanding the relationship between urban site conditions and tree growth is essential if remedial treatments are to be effective (Hodge and Boswell 1993; Mamy 1997). In order to achieve this goal, research is required to analyze and model the peculiar urban environmental conditions in order to identify tree growth patterns.

\section{MATERIALS AND METHODS}

\section{Study Site and Experimental Details}

The City of Montreal (Quebec, Canada) is located at latitude $45^{\circ} 30^{\prime} \mathrm{N}$ and longitude $73^{\circ} 34^{\prime} \mathrm{W}$. Climate is continental and humid, with hot summers and cold winters. The mean annual precipitation based on an almost 30-year span (1971-2000) is $1,062 \mathrm{~mm}$ (42 in) with a mean annual snow cover of $226 \mathrm{~cm}$ (88.9 in) (Environment Canada 2008). The mean daily maximum and minimum temperatures are $11^{\circ} \mathrm{C}\left(52^{\circ} \mathrm{F}\right)$ and $3^{\circ} \mathrm{C}$ $\left(37^{\circ} \mathrm{F}\right)$, respectively; extreme yearly minimum and maximum temperatures are typically $-34^{\circ} \mathrm{C}\left(-29^{\circ} \mathrm{F}\right)$ and $36^{\circ} \mathrm{C}\left(97^{\circ} \mathrm{F}\right)$. Annually, there are an average of 1,800 hours of sunshine, 2,335 degree-days below $10^{\circ} \mathrm{C}\left(50^{\circ} \mathrm{F}\right)$, and 1,399 degree-days above $10^{\circ} \mathrm{C}\left(50^{\circ} \mathrm{F}\right)$ (Environment Canada 2008). Frost occurs between October 1 and April 15; the typical snowfall season is from mid-November to the end of March (Boyer et al. 1985).

During the ice age, Montreal was completely covered by glaciers. When glacial ice retreated north, lowlands were invaded by the Atlantic Ocean, forming the Champlain Sea. Such processes deposited considerable amounts of clays and silts, which are frequently stratified, neutral to alkaline, and poorly drained; some sandy soils which are acid to neutral, usually characterized by rapid drainage; and finally tills, which evolved mostly into poorly drained loams, marine gravels, inter-fingered estuarine deposits, and coarse-grained alluvium (Brazeau 2003). Generally speaking, tills are the most abundant deposits with an approximate coverage of $46 \%$ of Montreal Island, clays are second with $23 \%$, and sands of all types (glacial, marine, and river) are estimated at $18 \%$. Other deposits are peat and marl, and rock (Prest and Keyser 1962). Overall, the City of Montreal has 4,460 km (2,734 mi) of roads, boulevards, and streets, where more than 240,000 public trees can be found.

To define the experimentation strategy and sample size, exploratory field work was carried out in 1999 and 2000 in different urban ecological zones. Once preliminary results from probing surveys were analyzed, sampling procedures were revised. Final data collection took place during summer 2001. Representative streets of downtown, institutional, commercial, and residential areas were selected following these criteria: height of buildings and geographic orientation (variable irradiance conditions), importance of vehicular and pedestrian use, size of tree pits, and width of street as trees beside a wide, heavily travelled street may be subjected to high salts and high winds (Berrang et al. 1985). Each studied street was assigned one of the following types: 1) intensive commercial, 2) commercial, 3) institutional, 4) intensive residential, and 5) residential.

Intensive commercial zones have the most severe urban strain and trees are normally slow-growing and very much damaged. Commercial zones exhibit less intense use but tree growth rates are only slow to fair. Tree caliber is normally larger than in the former zone. Institutional zones are mainly used by pedestrians and cars but mostly only to move around districts. Less mechanical damage occurs and trees may have fair to superior growth rates. Intensive residential zones have mid-level pedestrian and vehicle circulation. Trees have normally superior growth. Finally, residential zones are used by and large only by residents, and trees are typically vigorous.

For each surveyed downtown street, a systematic sampling was undertaken (total of 961 trees). In districts outside the downtown zone, trees were randomly selected within commercial, institutional, and residential environments (total of 571 trees). All trees were geopositioned on a geographical information system. The final cohort was composed of 1,532 trees of species that are representative of $75 \%$ of the City street trees population: Norway maple (Acer platanoides L.) (312 trees), silver maple (Acer saccharinum L.) (224), hackberry (Celtis occidentalis L.) (187), green ash (Fraxinus pennsylvanica Marsh.) (245), honeylocust (Gleditsia triacanthos L.) (301), littleleaf linden (Tilia cordata Mill.) (116), and Siberian elm (Ulmus pumila L.) (147).

Trees were sampled using 11 biotic variables identified as significant for urban tree inventories by multivariate statistical analyses (Jutras et al. 2009). These were diameter at breast height $(\mathrm{DBH})$, crown diameter, height, crown diameter / DBH, crown volume / DBH, height / DBH, crown volume, annual DBH increment, crown diameter increment, height increment and crown volume increment. The last four incremental variables are associated with size measurements. An annual crown volume increment was calculated as the difference between measured crown volume and crown volume at transplantation, divided by the number of years since transplantation. To obtain transplantation data, 15 City of Montreal nursery trees of ball-and-burlap transplanting size were measured for every species and mean values were calculated. Other incremental indices were similarly constructed.

Abiotic variables were selected for their ease of collection by end-users (arboriculture and horticulture city workers) once the model and methodology are deployed. The following parameters were used: street type (five classes as defined earlier) and orientation (calculated from a geographic information system), width of street, distance from tree to the closest nearby building, height of opposite and adjacent buildings (modulation of solar irradiation levels), volume of tree pit, penetration resistance at the surface, at $15 \mathrm{~cm}$ (5.9 in), $30 \mathrm{~cm}$ (11.8 in), and $45 \mathrm{~cm}$ (17.7 in) depths, type of tree pit ground cover (bare ground, rocks, grass, wood chips, etc.), presence of protective metal gratings at the base of trees (theoretical soil compaction reduction), distance from tree to street (indirect measurement of de-icing salt effect), presence of aerial and underground obstacles, and type of surficial geomorphologic deposit obtained from Prest and Keyser (1962). Four soil samples were collected at the edges of 796 tree pits $(0-20 \mathrm{~cm} / 0-8$ in depth) then mixed to form a composite for each tree pit. These samples were analyzed for $\mathrm{K}, \mathrm{Ca}, \mathrm{Mg}, \mathrm{Na}, \mathrm{Zn}, \mathrm{Cu}, \mathrm{Fe}, \mathrm{Mn}, \mathrm{P}, \mathrm{pH}$ level, and organic matter. 
For compaction measurements, an appropriate apparatus would be a nucleodensimeter. However, this piece of equipment requires specific expertise and a special operating permit as it is a nuclear device. To meet the objective of low-technology, an analog soil compaction gauge was tested as the sole device for penetration resistance assessment. In each sampled tree pit, four measures were taken, at each specified depth. To be able to compare results between tree pits, soil texture and moisture level must be similar. For that reason, particle-size analysis was carried out in the soil laboratory with the hydrometer method. Soils were classified as sandy loam or loamy sand. No direct soil moisture measurements were taken during field work. Accordingly, to make certain that soil moisture levels in tree pits were comparable when penetration resistance was measured, rainfall bulletins were checked at the end of field work. If there was any rainfall within five days prior to a collection date (data not presented), then the collected information was discarded. Consequently, the July 11, July 13, and August 24 data were rejected for analysis. The discarded samples accounted for $3 \%$ of the total (48 samples / 1,532 samples).

Because of the presence of urban canyons in the experimental design, the assessment of light levels on sampled trees was prioritized. In order to obtain local solar irradiation information, one possibility was to acquire data from climate stations. Although they provide reliable radiation records, they usually record radiation only for horizontal surfaces. Additionally, extrapolation of measurements from these collection sites to experimentation zones is difficult because, in practice, site-specific factors are difficult to remove from the original data (Flint and Childs 1987). Another option was to use existing algorithms modeling solar radiation (Annandale 2004; Bauerle et al. 2004; Groot 2004). Yet, most of these are very detailed models that did not suit the user-friendly needs of City of Montreal arboriculture practitioners. Therefore, a computer-programmed model was developed to automatically estimate the number of hours of irradiation on street trees and transfer this information to the database and the local geographic information system (Jutras 2008).

Input data for the model were latitude, longitude, Julian calendar, sunrise and sunset information per day; street orientation and width; mean height of adjacent and opposite buildings in a $50 \mathrm{~m}(164 \mathrm{ft})$ radius (arbitrary radius of influence); distance from tree to adjacent and opposite buildings; tree mid-crown elevation (calculated from morphological data) and position of tree pit on street. This information was combined using trigonometric formulae to compute irradiation values by minute per daytime. Output results were summarized into hourly, total daily, and seasonal irradiation per tree. Supplemental computa-

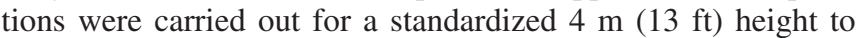
estimate tree pit potential irradiation for newly transplanted trees of ball \& burlap size. All irradiation levels were estimated from May 1 (normal earliest date of budburst: Hunter and Lechowicz 1992) to August 15 (end of active vegetative growth for northern trees: Harris and Bassuk 1995). Model output results were validated by collecting field data at specific times during 2003 and 2004 by ecological zone, size and height of trees.

Inevitably, such a model introduces bias as the estimation does not take into account parameters like intensity of direct beam radiation, amount of diffuse radiation, absorbed radiation, obstructed/unobstructed sky, or nearby buildingreflected radiation. Nevertheless, it was hypothesized the model might be accurate enough to measure the impact of reduced irradiation on urban tree growth as radiation calculations were transformed in five classes for the statistical analysis, hence eluding the need for an intricate model (next section).

In this experimental design, every tree was considered as a unit thus obviating the problems associated with subjective partitioning of the studied system into homogeneous zones. In order to do so, biophysical parameters were always collected in relation to a single tree.

\section{Statistical Analysis}

Contingency analysis is an interesting procedure to estimate dependence among descriptors that are not in monotonic relationship, or among qualitative descriptors. Tree-related data have such mathematical characteristics. In this research, contingency analysis was used to assess the relationship between urban tree growth and various states of local abiotic variables. Accordingly, prior to contingency analysis, the study authors searched for differential growth classes by using multivariate intermediate linkage clustering and correspondence analysis, the latter being a nonparametric principle component analysis (Jutras 2008).

Clustering is a useful tool when the description of surveyed individuals is multidimensional. Its goal is to partition a set of $n$ individuals into groups, called clusters, such that the individuals in each group are more similar to each other than to those in other groups (Friedman and Meulman 2004). Inputs for the clustering analysis were $\mathrm{DBH}$, crown diameter, height, crown diameter / DBH, crown volume / DBH, height / $\mathrm{DBH}$, crown volume, annual DBH increment, crown diameter increment, height increment, and crown volume increment. Outputs were species-specific groups with distinctive growth patterns. For this study, the detection of a maximum of four different clusters, from slow-growing to fast-growing trees, was sought in order that a robust classification model be deployed over the City of Montreal urban tree database. The final classifications were the following: Norway maple (3 growth groups); silver maple (3); hackberry (4); green ash (4); honeylocust (4); and Siberian elm (4).

Concurrently to this procedure, quantitative abiotic data were transformed into classes as required for contingency analysis. The conversion was accomplished by segmenting quantities into subsets representative of encountered ecological conditions (Table 1). Irradiation was divided into five classes; street width was subdivided into three classes: narrow (mostly residential), intermediate (encompassing all zone coding types), wide and very wide streets (commercial and institutional zones); nutrient subset classes were determined according to benchmark recommendations (Ministère de l'Agriculture et de l'Alimentation de l'Ontario 2003); counts of aerial and underground obstacles were converted to presence/ absence input. Surficial geomorphologic deposits associated with each tree location were classified into three types: 1) silty till and stony silty till, 2) clay and silty clay, and 3) sand and gravel.

The contingency analysis was carried out not only for every species but also on a combined all-species matrix. This research objective was to test model generalization. Species differed by their morphological characteristics and distribution of age classes among sampling sites, therefore potentially introducing high variability in the model algorithm. Consequently, if significant relationships between tree growth classes and certain abiotic parameters can be found, then a general model might be conceived. The all-species matrix was constructed to give 
equal representation to every species. Selection of individual trees was carried out in the following manner: the species with the least number of trees, littleleaf linden (116) was taken as a whole. For every other species, a random subset of 116 trees was singled out and added to the matrix for a total of 812 trees.

The significance of relationships in contingency tables was tested by using the Pearson $\chi^{2}$ statistic, a test that is known to be equivalent for qualitative descriptors to the covariance between quantitative descriptors (Legendre and Legendre 1998). This statistic measures the degree of interaction between two variables by computing the expected frequencies, according to a null hypothesis $\mathrm{H}_{0}$ and by comparing the observed $\left(\mathrm{O}_{\mathrm{ij}}\right)$ to the expected frequencies $\left(\mathrm{E}_{\mathrm{ij}}\right)$. In this research, $\mathrm{H}_{0}$ is the independence of the two variables and the significance level was set at 0.02 . The only postulation underlying the use of the $\chi^{2}$ is that the expected frequencies not be too small. If expected cell frequencies fall below 5 , the probabilities cannot be estimated with sufficient precision (Systat 2004; StatSoft 2006). In the latter case, it is more appropriate to use the Fisher's exact test and calculate associated probabilities (West and Hankin 2008). Computation of these probabilities is based on the assumption that the row and column classifications are independent (the null hypothesis)

Table 1. Conversion of quantitative abiotic variables into classes for contingency analysis.

\begin{tabular}{|c|c|c|c|c|c|}
\hline Variables & Class 1 & Class 2 & Class 3 & Class 4 & Class 5 \\
\hline $\begin{array}{l}\text { Total irradiation } \\
\text { May to August (hours) }\end{array}$ & $205-480$ & $481-755$ & $756-1030$ & $1031-1305$ & $1306-1615$ \\
\hline Street width $(\mathrm{m} / \mathrm{ft})$ & $\begin{array}{l}8.9-10.9 \\
(29.2-35.8)\end{array}$ & $\begin{array}{l}11.0-14.2 \\
(36.0-46.6)\end{array}$ & $\begin{array}{l}14.3-19.8 \\
(46.9-65.0)\end{array}$ & & \\
\hline $\begin{array}{l}\text { Distance from tree to } \\
\text { curb }(\mathrm{m} / \mathrm{ft})\end{array}$ & $\begin{array}{l}0.45-1.0 \\
(1.50-3.28)\end{array}$ & $\begin{array}{l}1.01-2.0 \\
(3.30-6.56)\end{array}$ & $\begin{array}{l}2.01-2.3 \\
(6.59-7.55)\end{array}$ & & \\
\hline $\begin{array}{l}\text { Tree pit volume } \\
\left(\mathrm{m}^{3} / \mathrm{ft}^{3}\right)\end{array}$ & $\begin{array}{l}1.0-2.0 \\
(35.3-70.6)\end{array}$ & $\begin{array}{l}2.1-3.0 \\
(74.2-105.9)\end{array}$ & $\begin{array}{l}3.1-5.0 \\
(109.5-176.6)\end{array}$ & $\begin{array}{l}5.1-9.6 \\
(180.1-339.0)\end{array}$ & \\
\hline $\begin{array}{l}\text { Penetration resistance } \\
\text { at soil surface }(\mathrm{kPa} / \mathrm{PSI})\end{array}$ & $\begin{array}{l}0-500 \\
(0.0-72.5)\end{array}$ & $\begin{array}{l}501-1000 \\
(72.7-145.0)\end{array}$ & $\begin{array}{l}1001-1500 \\
(145.2-217.5)\end{array}$ & $\begin{array}{l}1501-2000 \\
(217.7-290.1)\end{array}$ & \\
\hline $\begin{array}{l}\text { Penetration resistance } \\
\text { at } 15 \mathrm{~cm}(\mathrm{kPa} / \mathrm{PSI})\end{array}$ & $\begin{array}{l}0-500 \\
(0.0-72.5)\end{array}$ & $\begin{array}{l}501-1000 \\
(72.7-145.0)\end{array}$ & $\begin{array}{l}1001-1500 \\
(145.2-217.5)\end{array}$ & $\begin{array}{l}1501-2000 \\
(217.7-290.1)\end{array}$ & \\
\hline $\begin{array}{l}\text { Penetration resistance } \\
\text { at } 30 \mathrm{~cm}(\mathrm{kPa} / \mathrm{PSI})\end{array}$ & $\begin{array}{l}0-500 \\
(0.0-72.5)\end{array}$ & $\begin{array}{l}501-1000 \\
(72.7-145.0)\end{array}$ & $\begin{array}{l}1001-1500 \\
(145.2-217.5)\end{array}$ & $\begin{array}{l}1501-2000 \\
(217.7-290.1)\end{array}$ & \\
\hline $\begin{array}{l}\text { Penetration resistance } \\
\text { at } 45 \mathrm{~cm}(\mathrm{kPa} / \mathrm{PSI})\end{array}$ & $\begin{array}{l}0-500 \\
(0.0-72.5)\end{array}$ & $\begin{array}{l}501-1000 \\
(72.7-145.0)\end{array}$ & $\begin{array}{l}1001-1500 \\
(145.2-217.5)\end{array}$ & $\begin{array}{l}1501-2000 \\
(217.7-290.1)\end{array}$ & \\
\hline $\begin{array}{l}\text { Soil K } \\
(\mathrm{mg} / \mathrm{kg} \text { and oz/lb) }\end{array}$ & $\begin{array}{l}0-150 \\
(0.0-0.00239)\end{array}$ & $\begin{array}{l}151-250 \\
(0.00240-0.00400)\end{array}$ & $\begin{array}{l}251-350 \\
(0.00401-0.00560)\end{array}$ & $\begin{array}{l}351-450 \\
(0.00561-0.00721)\end{array}$ & $\begin{array}{l}451-650 \\
(0.00722-0.01040)\end{array}$ \\
\hline $\begin{array}{l}\text { Soil Ca } \\
\text { (mg/kg and oz/lb) }\end{array}$ & $\begin{array}{l}0-3000 \\
(0.0-0.0480)\end{array}$ & $\begin{array}{l}3001-5000 \\
(0.0481-0.0801)\end{array}$ & $\begin{array}{l}5001-8000 \\
(0.0802-0.1282)\end{array}$ & $\begin{array}{l}8001-11000 \\
(0.1283-0.1764)\end{array}$ & \\
\hline $\begin{array}{l}\text { Soil } \mathrm{Mg} \\
(\mathrm{mg} / \mathrm{kg} \text { and oz/lb) }\end{array}$ & $\begin{array}{l}0-175 \\
(0.0-0.00280)\end{array}$ & $\begin{array}{l}176-300 \\
(0.00281-0.00481)\end{array}$ & $\begin{array}{l}301-475 \\
(0.00482-0.00761)\end{array}$ & $\begin{array}{l}476-745 \\
(0.00762-0.0119)\end{array}$ & \\
\hline $\begin{array}{l}\text { Soil Na } \\
(\mathrm{mg} / \mathrm{kg} \text { and oz/lb) }\end{array}$ & $\begin{array}{l}0-250 \\
(0.0-0.0040)\end{array}$ & $\begin{array}{l}251-500 \\
(0.00401-0.00801)\end{array}$ & $\begin{array}{l}501-750 \\
(0.00802-0.01202)\end{array}$ & $\begin{array}{l}751-1000 \\
(0.01203-0.01603)\end{array}$ & $\begin{array}{l}1001-1758 \\
(0.01604-0.02819)\end{array}$ \\
\hline $\begin{array}{l}\text { Soil } \mathrm{Cu} \\
(\mathrm{mg} / \mathrm{kg} \text { and oz/lb) }\end{array}$ & $\begin{array}{l}0-7.0 \\
(0.0-0.000112)\end{array}$ & $\begin{array}{l}7.1-14.0 \\
(0.000113-0.000224)\end{array}$ & $\begin{array}{l}14.1-28.0 \\
(0.000225-0.000449)\end{array}$ & $\begin{array}{l}28.1-42.0 \\
(0.000450-0.000673)\end{array}$ & $\begin{array}{l}42.1-130 \\
(0.000674-0.00208)\end{array}$ \\
\hline $\begin{array}{l}\text { Soil Fe } \\
(\mathrm{mg} / \mathrm{kg} \text { and oz/lb) }\end{array}$ & $\begin{array}{l}145-210 \\
(0.00232-0.00337)\end{array}$ & $\begin{array}{l}211-280 \\
(0.00338-0.00449)\end{array}$ & $\begin{array}{l}281-350 \\
(0.00450-0.00561)\end{array}$ & $\begin{array}{l}351-615 \\
(0.00562-0.00986)\end{array}$ & \\
\hline $\begin{array}{l}\text { Soil Mn } \\
\text { (mg/kg and oz/lb) }\end{array}$ & $\begin{array}{l}0-15.0 \\
(0.0-0.000240)\end{array}$ & $\begin{array}{l}15.1-30.0 \\
(0.000241-0.000481)\end{array}$ & $\begin{array}{l}30.1-45.0 \\
(0.000482-0.000721)\end{array}$ & $\begin{array}{l}45.1-106 \\
(0.000722-0.001699)\end{array}$ & \\
\hline $\begin{array}{l}\text { Soil P } \\
(\mathrm{mg} / \mathrm{kg} \text { and } \mathrm{oz} / \mathrm{lb})\end{array}$ & $\begin{array}{l}0-80 \\
(0.0-0.00128)\end{array}$ & $\begin{array}{l}81-160 \\
(0.00129-0.00256)\end{array}$ & $\begin{array}{l}161-240 \\
(0.00257-0.00385)\end{array}$ & $\begin{array}{l}241-320 \\
(0.00386-0.00513)\end{array}$ & $\begin{array}{l}321-730 \\
(0.00514-0.01170)\end{array}$ \\
\hline Soil pH & $5.2-6.0$ & $6.1-6.5$ & $6.6-7.0$ & $7.1-7.5$ & $7.6-8.3$ \\
\hline $\begin{array}{l}\text { Soil organic matter } \\
\text { content }(\%)\end{array}$ & $0.0-5.0$ & $5.1-10.0$ & $10.1-15.0$ & $15.1-20.0$ & $20.1-26.8$ \\
\hline
\end{tabular}


and that the row and column totals are fixed (Sokal and Rohlf 1995). Given the fact that this test is impossible to perform for most data sets as the total number of cases increases rapidly (Raymond and Rousset 1995), different methods were proposed to obtain an unbiased estimate of the exact $P$-values (Guo and Thompson 1989; Guo and Thompson 1992). In the research presented here, whenever Fisher's test was required because of small cell frequencies, the Metropolis algorithm was utilized. Related probabilities were computed by analyzing 20 successive batches, each composed of 2,500 replicates, for an overall total of 50,000 replicates. In order to obtain unbiased estimates, a random arbitrary start state was set after 1,000 dememorization steps. Statistical analyses were performed using Systat ${ }^{\circledR}$ (Systat 2004), and Statistica ${ }^{\circledR}$ (StatSoft 2006). The Fisher's exact test was computed using the program developed by Miller (2009).

\section{RESULTS AND DISCUSSION}

Contingency results are presented in Table 2 as probabilities associated either with the Pearson chi-square statistic or Fisher's exact test. Significant results (rejection of $\mathrm{H}_{0}$ : tree growth being considered not influenced by specific local environmental conditions) are marked. Overall, presence/absence of metal grating, urban zone type, surficial deposit, presence/absence of aerial and underground obstacles, irradiation, street width, distance from tree to curb, tree pit soil volume, and penetration resistance were central parameters for many or all species. On the other hand, soil nutrients were only sporadically identified as significant elements thereby their importance as explaining factors for tree growth status is relatively low. This outcome is most likely related to the fact that, when sidewalks are present, soil samples can only be collected within the transplantation pit opening which is usually $1.5 \mathrm{~m}$ $(4.9 \mathrm{ft})$ x $1.5 \mathrm{~m}(4.9 \mathrm{ft})$ or less. With their extensive perennial root systems, trees integrate nutrient bioavailability not only near their trunk but mostly throughout the soil profile (Brady and Weil 2002).

Originally, the purpose of noting the presence of metal gratings over tree pits was to test their potentially positive influence on tree-pit soil compaction. Within the limits of the soil compaction methodology and apparatus utilized, one can infer that there is no quantifiable impact. Their presence obviously limits pedestrian compaction but probably cannot prevent detrimental vibrational forces due to heavy and dense urban traffic on commercial streets (Craul 1992; Craul 1999). This statement is illustrated by a contingency analysis between presence/absence of metal grating and the different classes of penetration resistance at the surface, and at depths of $15 \mathrm{~cm}$ (5.9 in), $30 \mathrm{~cm}$ (11.8 in), and $45 \mathrm{~cm}$ (17.7 in). These two variables are independent (Table 3). Nonetheless in the overall analysis (Table 2), presence of protec-

Table 2. Pearson $\chi^{2}$ and Fisher's exact test results on the significance of the relationship between growth classes and abiotic parameters, according to a null hypothesis $\mathrm{H}_{0}$ where tree growth is considered not influenced by specific local environmental conditions. $^{\text {.yx }}$

\begin{tabular}{|c|c|c|c|c|c|c|c|c|}
\hline Parameters & $\begin{array}{l}\text { Norway } \\
\text { maple }\end{array}$ & $\begin{array}{l}\text { Silver } \\
\text { maple }\end{array}$ & Hackberry & $\begin{array}{l}\text { Green } \\
\text { ash }\end{array}$ & Honeylocust & $\begin{array}{l}\text { Littleleaf } \\
\text { linden }\end{array}$ & $\begin{array}{l}\text { Siberian } \\
\text { elm }\end{array}$ & All-species \\
\hline Metal grating (Yes/No) & $0.00 \mathrm{a}$ & $0.00 \mathrm{a}$ & 0.00 a & 0.00 a & 0.00 a & - & $0.31 \mathrm{~b}$ & 0.00 a \\
\hline Soil Cover (Yes/No) & $0.25 \mathrm{a}$ & $0.08 \mathrm{a}$ & $0.12 \mathrm{~b}$ & 0.01 a & $0.07 \mathrm{~b}$ & $0.25 \mathrm{~b}$ & 0.01 a & $0.04 \mathrm{a}$ \\
\hline Surficial deposit (3 Types) & 0.00 a & $0.10 \mathrm{a}$ & $0.07 \mathrm{~b}$ & $0.00 \mathrm{a}$ & $0.00 \mathrm{a}$ & $0.04 \mathrm{~b}$ & $0.23 \mathrm{a}$ & $0.00 \mathrm{a}$ \\
\hline Aerial obstacles (Yes/No) & $0.00 \mathrm{~b}$ & $0.16 \mathrm{~b}$ & $0.00 \mathrm{~b}$ & $0.04 \mathrm{~b}$ & $0.46 \mathrm{~b}$ & $0.00 \mathrm{~b}$ & $0.07 \mathrm{~b}$ & $0.07 \mathrm{a}$ \\
\hline $\begin{array}{l}\text { Underground obstacles } \\
\text { (Yes/No) }\end{array}$ & $0.39 \mathrm{~b}$ & $0.17 \mathrm{a}$ & $0.06 \mathrm{~b}$ & $0.01 \mathrm{~b}$ & $0.00 \mathrm{~b}$ & $0.00 \mathrm{~b}$ & $0.02 b$ & $0.00 \mathrm{~b}$ \\
\hline Street width (3 Classes) & 0.02 a & $0.04 \mathrm{a}$ & $0.00 \mathrm{~b}$ & 0.00 a & $0.00 \mathrm{a}$ & $0.00 \mathrm{~b}$ & 0.00 a & $0.00 \mathrm{a}$ \\
\hline $\begin{array}{l}\text { Distance from tree to curb } \\
\text { (3 Classes) }\end{array}$ & $0.01 \mathrm{~b}$ & $0.53 \mathrm{~b}$ & $0.04 \mathrm{~b}$ & $0.46 \mathrm{~b}$ & $0.00 \mathrm{~b}$ & $0.05 \mathrm{~b}$ & $0.75 \mathrm{~b}$ & $0.01 b$ \\
\hline $\begin{array}{l}\text { Tree pit soil volume } \\
\text { (4 Classes) }\end{array}$ & $0.28 \mathrm{~b}$ & $0.05 \mathrm{~b}$ & $0.07 \mathrm{~b}$ & $0.04 \mathrm{~b}$ & $0.02 b$ & $0.01 b$ & $0.00 \mathrm{~b}$ & $0.00 \mathrm{~b}$ \\
\hline $\begin{array}{l}\text { Penetration resistance } \\
\text { at surface ( } 4 \text { Classes) }\end{array}$ & $0.01 \mathrm{a}$ & $0.03 \mathrm{a}$ & $0.04 \mathrm{a}$ & $0.00 \mathrm{a}$ & $0.05 \mathrm{a}$ & $0.96 \mathrm{a}$ & $0.00 \mathrm{~b}$ & 0.00 a \\
\hline $\begin{array}{l}\text { Penetration resistance } \\
\text { at } 15 \mathrm{~cm}(5.9 \mathrm{in})(4 \text { Classes })\end{array}$ & 0.02 a & $0.00 \mathrm{~b}$ & $0.00 \mathrm{~b}$ & $0.00 \mathrm{a}$ & $0.00 \mathrm{~b}$ & $0.00 \mathrm{~b}$ & $0.00 \mathrm{~b}$ & 0.00 a \\
\hline $\begin{array}{l}\text { Penetration resistance } \\
\text { at } 45 \mathrm{~cm}(17.7 \text { in })(4 \text { Classes })\end{array}$ & $0.19 \mathrm{~b}$ & $0.00 \mathrm{~b}$ & $0.01 b$ & $0.13 \mathrm{~b}$ & $0.02 b$ & $0.36 \mathrm{~b}$ & $0.01 b$ & $0.00 \mathrm{~b}$ \\
\hline Soil K - (5 Classes) & $0.47 \mathrm{~b}$ & $0.54 \mathrm{~b}$ & $0.03 \mathrm{~b}$ & $0.33 \mathrm{~b}$ & $0.25 \mathrm{~b}$ & $0.25 \mathrm{~b}$ & $0.00 \mathrm{~b}$ & $0.56 \mathrm{~b}$ \\
\hline Soil Ca - (4 Classes) & $0.74 \mathrm{~b}$ & $0.37 \mathrm{~b}$ & $0.45 \mathrm{~b}$ & $0.78 \mathrm{~b}$ & $0.67 \mathrm{~b}$ & $0.11 \mathrm{~b}$ & $0.05 \mathrm{~b}$ & $0.09 \mathrm{~b}$ \\
\hline Soil Mg - (4 Classes) & $0.67 \mathrm{~b}$ & $0.38 \mathrm{~b}$ & $0.28 \mathrm{~b}$ & $0.18 \mathrm{~b}$ & $0.05 \mathrm{~b}$ & $0.19 \mathrm{~b}$ & $0.41 \mathrm{~b}$ & $0.31 \mathrm{~b}$ \\
\hline Soil Na - (5 Classes) & $0.44 \mathrm{~b}$ & $0.31 \mathrm{~b}$ & $0.13 \mathrm{~b}$ & $0.66 \mathrm{~b}$ & $0.02 b$ & $0.99 \mathrm{~b}$ & $0.52 \mathrm{~b}$ & $0.02 b$ \\
\hline Soil Zn - (5 Classes) & $0.03 \mathrm{~b}$ & $0.40 \mathrm{~b}$ & $0.04 \mathrm{~b}$ & $0.19 \mathrm{~b}$ & $0.00 \mathrm{~b}$ & $0.06 \mathrm{~b}$ & $0.77 \mathrm{~b}$ & $0.07 \mathrm{~b}$ \\
\hline Soil $\mathrm{Cu}$ - (5 Classes $)$ & $0.41 \mathrm{~b}$ & $0.13 \mathrm{~b}$ & $0.18 \mathrm{~b}$ & $0.51 \mathrm{~b}$ & $0.01 b$ & $0.00 \mathrm{~b}$ & $0.28 \mathrm{~b}$ & $0.12 \mathrm{~b}$ \\
\hline Soil Fe - (4 Classes) & $0.68 \mathrm{~b}$ & $0.07 \mathrm{~b}$ & $0.01 b$ & $0.83 \mathrm{~b}$ & $0.28 \mathrm{~b}$ & $0.10 \mathrm{~b}$ & $0.36 \mathrm{~b}$ & $0.46 \mathrm{~b}$ \\
\hline Soil Mn - (4 Classes) & $0.06 \mathrm{~b}$ & $0.31 \mathrm{~b}$ & $0.08 \mathrm{~b}$ & $0.01 b$ & $0.06 \mathrm{~b}$ & $0.15 \mathrm{~b}$ & $0.00 \mathrm{~b}$ & $0.01 \mathrm{~b}$ \\
\hline Soil P - (5 Classes $)$ & $0.27 \mathrm{~b}$ & $0.52 \mathrm{~b}$ & $0.68 \mathrm{~b}$ & $0.28 \mathrm{~b}$ & $0.10 \mathrm{~b}$ & $0.71 \mathrm{~b}$ & $0.46 \mathrm{~b}$ & $0.53 \mathrm{~b}$ \\
\hline $\mathrm{pH}-(5$ Classes $)$ & $0.51 \mathrm{~b}$ & $0.04 \mathrm{~b}$ & $0.37 \mathrm{~b}$ & $0.26 \mathrm{~b}$ & $0.81 \mathrm{~b}$ & $0.29 \mathrm{~b}$ & $0.12 \mathrm{~b}$ & $0.52 \mathrm{~b}$ \\
\hline $\begin{array}{l}\text { Soil organic matter } \\
\text { (5 Classes) }\end{array}$ & $0.83 \mathrm{~b}$ & $0.42 \mathrm{~b}$ & $0.45 \mathrm{~b}$ & $0.08 \mathrm{~b}$ & $0.00 \mathrm{~b}$ & $0.43 \mathrm{~b}$ & $0.00 \mathrm{~b}$ & $0.01 b$ \\
\hline
\end{tabular}

${ }^{\mathrm{z}}$ Probabilities where $\mathrm{H}_{0}$ is rejected (significance level $\alpha \leq 0.02$ ) are highlighted in bold type.

y Pearson chi-square probabilities are followed by "a".

"Fisher's exact test probabilities are followed by "b". 
Table 3. Contingency analysis of presence/absence of metal grating and penetration resistance (frequencies per class).

\begin{tabular}{|c|c|c|c|c|c|c|}
\hline \multirow[t]{2}{*}{ Sampling zone } & \multirow{2}{*}{$\begin{array}{l}\text { Metal } \\
\text { grating }\end{array}$} & \multicolumn{4}{|c|}{ Penetration resistance } & \multirow{2}{*}{$\begin{array}{r}\text { Pearson } \\
\chi^{2} \text { statistic } \\
\end{array}$} \\
\hline & & Class 1 & Class 2 & Class 3 & Class 4 & \\
\hline \multirow[t]{2}{*}{ Surface level } & Absence & $29 \%$ & $26 \%$ & $22 \%$ & $23 \%$ & \multirow[t]{2}{*}{$10.26^{2}$} \\
\hline & Presence & $36 \%$ & $25 \%$ & $13 \%$ & $26 \%$ & \\
\hline \multirow{2}{*}{$\begin{array}{l}15 \mathrm{~cm} \text { depth } \\
(5.9 \mathrm{in})\end{array}$} & Absence & $7 \%$ & $16 \%$ & $15 \%$ & $62 \%$ & \multirow[t]{2}{*}{$3.45^{2}$} \\
\hline & Presence & $11 \%$ & $15 \%$ & $16 \%$ & $58 \%$ & \\
\hline $\begin{array}{l}30 \mathrm{~cm} \text { depth } \\
(11.8 \mathrm{in})\end{array}$ & Absence & $2 \%$ & $8 \%$ & $12 \%$ & $78 \%$ & $7.26^{2}$ \\
\hline \multirow{2}{*}{$\begin{array}{l}45 \mathrm{~cm} \text { depth } \\
(17.7 \mathrm{in})\end{array}$} & Absence & $2 \%$ & $3 \%$ & $6 \%$ & $89 \%$ & \multirow[t]{2}{*}{$9.59^{z}$} \\
\hline & Presence & $3 \%$ & $4 \%$ & $7 \%$ & $86 \%$ & \\
\hline
\end{tabular}

${ }^{\mathrm{z}} \mathrm{H}_{\mathrm{o}}$ : independence of variables not rejected (significance level $\alpha$ is $>0.01$ ).

tive metal grating was a highly significant parameter for most species. A possible explanation is that, as gratings are found only on commercial streets, their influence is confounded by the strong relationship between urban tree growth and type of urban zone.

Urban zones are defined by unique patterns of growing space, tree canopy cover, and housing density (Nilon 1991). In a Missouri, U.S. study, trees in commercial zones averaged $24 \mathrm{~cm}(9.5$ in) $\mathrm{DBH}$, but mixed commercial/residential trees $(29 \mathrm{~cm} / 11.5 \mathrm{in})$ and residential trees $(31 \mathrm{~cm} / 12.2 \mathrm{in})$ were larger (Gartner et al. 2002). Comparable figures were obtained during the course of this study. For species taken together, annual mean DBH increments for intensive commercial zones (Type 1) and commercial zones (Type 2) were respectively $0.53 \mathrm{~cm} /$ year $(0.21 \mathrm{in} /$ year) and $0.78 \mathrm{~cm} /$ year $(0.31 \mathrm{in} /$ year), while values for institutional (Type 3), intensive residential (Type 4), and residential (Type 5) were $1.18 \mathrm{~cm} /$ year $(0.46 \mathrm{in} /$ year $), 1.03 \mathrm{~cm} /$ year $(0.41$ in/year), and $1.02 \mathrm{~cm} /$ year ( $0.40 \mathrm{in} /$ year), respectively. More particularly, for each significant species contingency result (refer to Table 2), stressed trees were primarily found in commercial zones 1 and 2 (details in Table 4). For example, when examining the distribution of trees in the all-species matrix, it can be seen that $82 \%$ of the poorly growing trees were located in these sectors. Likewise, normal-growing or vigorously-growing trees were found in intensive residential and residential areas. Yet, for most species, such normally or vigorous trees were also found in Zones 2 and 3, indicating trees can withstand harsh environmental conditions. The all-species fast-growing class typifies this last assertion: a total of $45 \%$ of the studied trees are associated with commercial and institutional areas (Table 4). All other things being equal, this phenomenon might be explained by the influence of irradiation levels on growth patterns.

Uneven irradiation intensity is a trait of the urban environment. When comparing studied residential and commercial streets, differences were found in the distribution of irradiation levels. Residential areas in Montreal are typically one to four-story buildings. For this reason, most residential streets receive relatively important light levels (mean irradiation value of 1,495 hours during the active vegetative growth period). On the contrary, irradiation of commercial zones varies and trees can be exposed to total light levels as low as 205-480 hours. Previous research from Kjelgren (1995) estimated that $70 \%-85 \%$ potential irradiance is a threshold level for increased or decreased leaf area, trunk growth, and crown density of Norway maple 'Emerald Queen' trees. Results from our study support this affirmation not only for this species but also for silver maple, hackberry, green ash, honeylocust, and Siberian elm. When growth patterns of these species were projected with irradiation levels in commercial zones, it was found that light levels influenced class membership (Figure 1). For instance, the best growing classes for Norway maple, silver maple, green ash, and honeylocust were respectively associated with $81 \%, 83 \%, 80 \%$, and $88 \%$ of total potential irradiation estimated with our algorithm at the latitude of Montreal and with no physical barriers to light interception (a maximum of 1,615 hours during the active vegetative growth period). Similarly, hackberry and Siberian elm best growth classes were associated with $99 \%$ and $98 \%$ of total potential irradiation, respectively.

In order to compare these results with the potential light conditions at transplantation time, irradiation levels were computed at a height of $4 \mathrm{~m}$ rather than mid-crown elevation for every sampled tree pit in commercial zones. Tree pits associated with slow growing trees had a $4 \mathrm{~m}$ mean irradiation value of 1,182 hours ( $73 \%$ of total potential irradiation), while those related

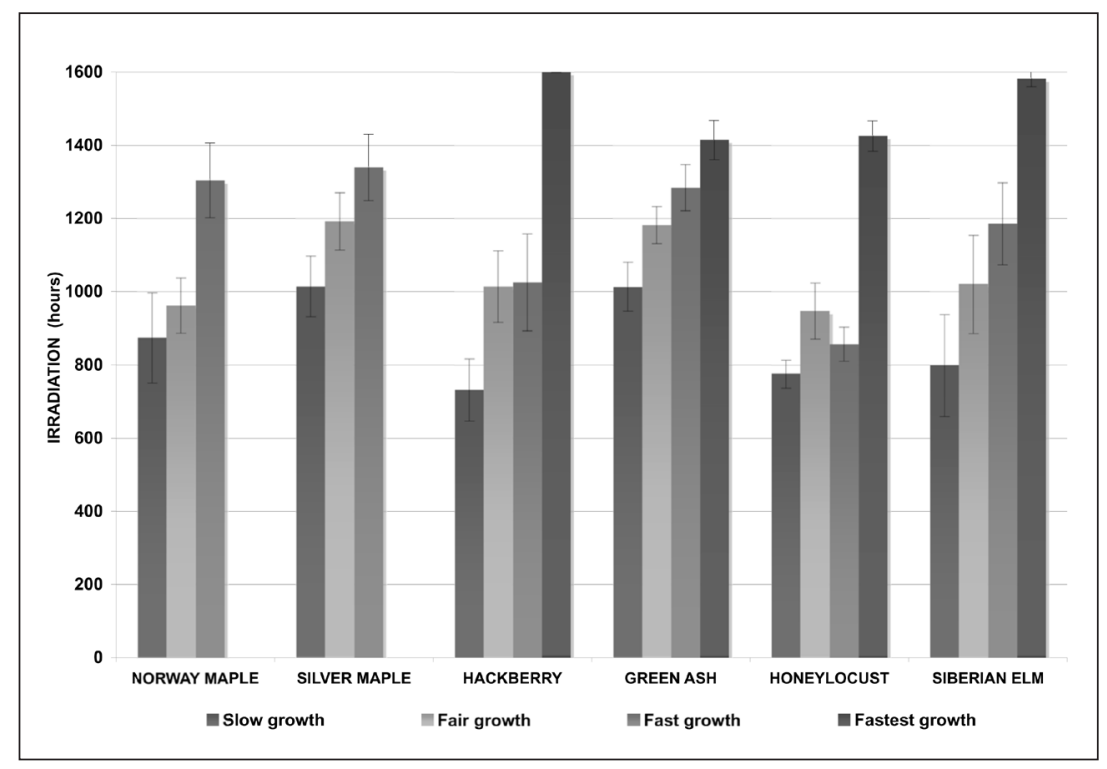

Figure 1. Irradiation levels per species and growth rate in commercial zones (mean values \pm standard error). 
to the best growing class had a mean irradiation level of 1,408 hours ( $87 \%$ of total potential irradiation). Such figures indicate adequate growth might be promoted when trees are transplanted in a favorable light environment, even in the most restrictive abiotic conditions. It must be noted that littleleaf linden was excluded from this discussion because there were no trees sampled in commercial settings. This species is rarely transplanted in such an environment because of its high sensitivity to de-icing salts.

Street width and distance from transplantation pit to curb are important urban characteristics that impose restrictions on tree growth. Proximity of the trunk to the curb may imply physical impediment to trunk growth and crown restriction due to traffic and safety requirements (Jim 1997), and greater exposure to de-icing salts. In contrast, being close to the street is normally associated with higher irradiation levels as trees are farther from buildings. As well, wide streets mean busy ones with polluted air that may dampen tree growth (Jim 1997). Above all, de-ic- ing salts and de-icing salt spray are probably the most deleterious pollutants to trees. Paul (1997) found that trees growing in soils with high salt levels tended to have more twig dieback and less twig growth than those growing in soils with lower salt levels. Traffic intensity and traffic speed are considered to be of special significance with respect to salt damage (Hootman et al. 1994). When salts are applied to roads, the salt in the spray generated by traffic may be more damaging to plants than the salt that drains into the soil. Trees that are the most tolerant to soil salinity may not necessarily be the most tolerant to salt spray or mist on foliage, and vice versa (Harris et al. 1999).

Table 5 points out the relationships between de-icing salt concentration, street width, and distance from tree to curb. Results substantiate the above discussion as higher soil salt concentrations were found when trees were transplanted into tree pits closer to curb and on wider streets. Whenever possible, a special attention must be paid to such urban locations: tree pits design

Table 4. Frequencies in the contingency analysis between species-specific tree growth patterns and studied urban zones.

\begin{tabular}{|c|c|c|c|c|c|c|}
\hline \multirow[t]{2}{*}{ Species } & \multirow[t]{2}{*}{ Growth rate } & \multicolumn{5}{|c|}{ Urban zones ${ }^{z}$} \\
\hline & & 1 & 2 & 3 & 4 & 5 \\
\hline \multirow[t]{3}{*}{ Norway maple } & Slow & $69 \%$ & $14 \%$ & $11 \%$ & $5 \%$ & $1 \%$ \\
\hline & Fair & $14 \%$ & $34 \%$ & $12 \%$ & $25 \%$ & $15 \%$ \\
\hline & Fast & $1 \%$ & $19 \%$ & $12 \%$ & $41 \%$ & $27 \%$ \\
\hline \multirow[t]{4}{*}{ Hackberry } & Slow & $30 \%$ & $50 \%$ & $2 \%$ & $9 \%$ & $9 \%$ \\
\hline & Fair & $8 \%$ & $35 \%$ & $0 \%$ & $35 \%$ & $22 \%$ \\
\hline & Fast & $8 \%$ & $37 \%$ & $0 \%$ & $12 \%$ & $43 \%$ \\
\hline & Fastest & $0 \%$ & $3 \%$ & $0 \%$ & $16 \%$ & $81 \%$ \\
\hline \multirow[t]{4}{*}{ Green ash } & Slow & $20 \%$ & $80 \%$ & $0 \%$ & $0 \%$ & $0 \%$ \\
\hline & Fair & $23 \%$ & $55 \%$ & $3 \%$ & $2 \%$ & $17 \%$ \\
\hline & Fast & $3 \%$ & $56 \%$ & $0 \%$ & $0 \%$ & $41 \%$ \\
\hline & Fastest & $1 \%$ & $28 \%$ & $0 \%$ & $15 \%$ & $56 \%$ \\
\hline \multirow[t]{4}{*}{ Honeylocust } & Slow & $23 \%$ & $68 \%$ & - & $2 \%$ & $7 \%$ \\
\hline & Fair & $6 \%$ & $80 \%$ & - & $8 \%$ & $6 \%$ \\
\hline & Fast & $9 \%$ & $74 \%$ & - & $3 \%$ & $14 \%$ \\
\hline & Fastest & $2 \%$ & $33 \%$ & - & $11 \%$ & $54 \%$ \\
\hline \multirow[t]{2}{*}{ Littleleaf linden } & Slow & - & - & $72 \%$ & $3 \%$ & $25 \%$ \\
\hline & Fast & - & - & $4 \%$ & $17 \%$ & $79 \%$ \\
\hline \multirow[t]{4}{*}{ Siberian elm } & Slow & - & $93 \%$ & $7 \%$ & - & - \\
\hline & Fair & - & $53 \%$ & $47 \%$ & - & - \\
\hline & Fast & - & $39 \%$ & $61 \%$ & - & - \\
\hline & Fastest & - & $39 \%$ & $61 \%$ & - & - \\
\hline \multirow[t]{4}{*}{ All species matrix } & Slow & $26 \%$ & $56 \%$ & $8 \%$ & $2 \%$ & $8 \%$ \\
\hline & Fair & $13 \%$ & $53 \%$ & $17 \%$ & $9 \%$ & $8 \%$ \\
\hline & Fast & $4 \%$ & $23 \%$ & $18 \%$ & $13 \%$ & $42 \%$ \\
\hline & Fastest & $2 \%$ & $28 \%$ & $6 \%$ & $11 \%$ & $53 \%$ \\
\hline
\end{tabular}

${ }^{\mathrm{z}}$ Urban zones: 1) Commercial intensive, 2) Commercial, 3) Institutional, 4) Residential intensive, 5) Residential.

Table 5. Percentage of de-icing salt class per street width and distance from trunk to curb class.

\begin{tabular}{|c|c|c|c|c|c|c|}
\hline & & \multicolumn{5}{|c|}{ De-icing salts (mg/kg and oz/lb of $\mathrm{Na})$} \\
\hline & & $\begin{array}{l}0-250^{z} \\
(0.0- \\
0.0040)\end{array}$ & $\begin{array}{l}251-500 \\
(0.00401- \\
0.00801)\end{array}$ & $\begin{array}{l}501-750 \\
(0.00802- \\
0.01202)\end{array}$ & $\begin{array}{l}751-1000 \\
(0.01203- \\
0.01603)\end{array}$ & $\begin{array}{l}1001-1758 \\
(0.01604- \\
0.02819)\end{array}$ \\
\hline \multirow[t]{2}{*}{$\begin{array}{l}\text { Street width } \\
(\mathrm{m} / \mathrm{ft})\end{array}$} & $\begin{array}{l}8.9-10.9 \\
(29.2-35.8)\end{array}$ & $87.1 \%$ & $9.6 \%$ & $2.9 \%$ & $0.4 \%$ & $0.0 \%$ \\
\hline & $\begin{array}{l}11.0-14.2 \\
(36.0-46.6)\end{array}$ & $75.4 \%$ & $15.6 \%$ & $5.7 \%$ & $1.6 \%$ & $1.6 \%$ \\
\hline \multirow[t]{2}{*}{$\begin{array}{l}\text { Distance trunk to curb } \\
(\mathrm{m} / \mathrm{ft})\end{array}$} & $\begin{array}{l}0.45-1.0 \\
(1.48-3.28)\end{array}$ & $78.3 \%$ & $14.1 \%$ & $5.1 \%$ & $1.3 \%$ & $1.2 \%$ \\
\hline & $\begin{array}{l}1.01-2.0 \\
(3.31-6.56)\end{array}$ & $89.1 \%$ & $8.7 \%$ & $2.2 \%$ & $0.0 \%$ & $0.0 \%$ \\
\hline
\end{tabular}

${ }^{\mathrm{z}}$ According to Hootman et al. (1994), $250 \mathrm{mg} / \mathrm{kg}$ is the threshold to be considered as excessive for most trees. 
should preferably minimize the infiltration of de-icing salts into soil, broadcasting machinery should be frequently calibrated and dosage reduced to the minimum acceptable level. Salt-tolerant species selection is also critical: only the right plant will have the ability to survive and thrive (Watson and Himelick 1997).

Trees within the experimental protocol were distributed among three soil types. Clayey soils were associated with $57 \%$ of tree locations, sandy soils with $27 \%$, and tills with $23 \%$. With such statistics, one might expect a strong abiotic effect related to clays. Yet, contingency analysis depicted a different result. For species exhibiting significant relationships (refer to Table 2) the most important outcome was the presence/absence of sand and gravel. In all cases, limited growth rates were closely linked to presence of sand/gravel deposits (Table 6). Conversely, distribution of clusters within tills and clay soils demonstrated no such tendency.

Urban planting site evaluation requires the assessment of local soil types. Generally speaking, professionals primarily consider the presence of clays as they are poorly drained soils that frequently limit planting success. It is well known that, in many cases, newly planted urban trees die when roots "drown" from too much water (Watson and Himelick 1997). Nonetheless, the contingency analysis results suggest that sand/ gravel textured soils should also be closely looked upon as an important limiting factor. These soils have a low water holding capacity. When they dry out, the rapid decrease in soil water potential places the vegetation under great stress. In addition, they are characterized with a low cation-exchange capacity and readily loose nutrients through leaching (Craul 1992).

\begin{tabular}{|c|c|c|c|c|}
\hline \multirow[t]{2}{*}{ Species } & \multirow[t]{2}{*}{ Growth rate } & \multicolumn{3}{|c|}{ Surficial deposits } \\
\hline & & Till & Clay & Sand-gravel \\
\hline \multirow[t]{3}{*}{ Norway maple } & Slow & $7 \%$ & $38 \%$ & $55 \%$ \\
\hline & Fair & $28 \%$ & $31 \%$ & $41 \%$ \\
\hline & Fast & $34 \%$ & $40 \%$ & $26 \%$ \\
\hline \multirow[t]{4}{*}{ Green ash } & Slow & $2 \%$ & $58 \%$ & $40 \%$ \\
\hline & Fair & $16 \%$ & $63 \%$ & $21 \%$ \\
\hline & Fast & $19 \%$ & $65 \%$ & $16 \%$ \\
\hline & Fastest & $16 \%$ & $77 \%$ & $7 \%$ \\
\hline \multirow[t]{4}{*}{ Honeylocust } & Slow & $11 \%$ & $57 \%$ & $31 \%$ \\
\hline & Fair & $13 \%$ & $70 \%$ & $17 \%$ \\
\hline & Fast & $16 \%$ & $67 \%$ & $17 \%$ \\
\hline & Fastest & $43 \%$ & $52 \%$ & $5 \%$ \\
\hline \multirow[t]{4}{*}{ All-species matrix } & Slow & $10 \%$ & $48 \%$ & $42 \%$ \\
\hline & Fair & $27 \%$ & $46 \%$ & $27 \%$ \\
\hline & Fast & $23 \%$ & $57 \%$ & $20 \%$ \\
\hline & Fastest & $29 \%$ & $51 \%$ & $20 \%$ \\
\hline
\end{tabular}

\section{SUMMARY AND CONCLUSIONS}

Frequently, studies of urban effects on street tree stress can become largely descriptive because the geographic separation between study trees results in the confounding of innumerable factors and precludes rigorous hypothesis testing (Cregg and Dix 2001). Within the scope of this research, use of contingency analysis circumvented this difficulty and noteworthy conclusions were derived.

Analyses with the Pearson $\chi^{2}$ statistic and Fisher's exact test brought out central parameters related to differential street tree growth. Among them, urban zone type, surficial deposit, irradiation level, street width, and distance from tree to curb were the most important. Unsurprisingly, stressed trees were found primarily in intensive commercial and commercial zones. In contrast, normally-growing or vigorous trees were found not only in intensive residential and residential areas, but also in commercial and institutional zones indicating that the species under study can tolerate harsh environments. In this situation, ample irradiation intensity might be an important factor contributing to satisfactory urban tree growth. All other things being equal, contingency analysis led to the identification of a threshold level above which adequate growth was found in commercial zones for Norway maple, silver maple, hackberry, green ash, honeylocust, and Siberian elm. Minimally, $80 \%$ of total potential irradiation estimated with the algorithm at the latitude of Montreal (1,285 hours during the active vegetative growth period) is required for optimal growth. Research results also illustrated the importance of the underlying surficial deposits. In all cases, slow growth rates were closely linked to the presence of sand/gravel deposits. Finally, higher soil de-icing salt concentrations were found in tree pits where trees were transplanted closer to the curb and on wider streets.

The geographic location of Montreal entails particular environmental conditions and any extrapolation of the findings of this study to other tree species, urban conditions and/or geographic location should be made with caution. Nevertheless, it is suggested that the assessment of these abiotic parameters become an essential component of street-tree management programs in order that pre- and post-transplantation procedures be specifically adapted to the local urban environmental conditions.

Acknowledgments. The authors are grateful for the financial support of City of Montreal and the Natural Science and Engineering Research Council of Canada (NSERC). We also express gratitude to anonymous reviewers for their pertinent comments on the original manuscript.

\section{LITERATURE CITED}

Annandale, J.G., N.Z. Jovanovic, G.S. Campbell, N. Du Sautoy, and P. Lobit. 2004. Two-dimensional solar radiation interception model for hedgerow fruit trees. Agricultural and Forest Meteorology 121:207-225.

Ball, J., S. Mason, A. Kiesz, D. McCormick, and C. Brown. 2007. Assessing the hazard of emerald ash borer and other exotic stressors to community forests. Arboriculture \& Urban Forestry 33:350-359.

Bauerle, W.L., J.D. Bowden, M.F. McLeod, and J.E. Toler. 2004. Modeling intra-crown and intra-canopy interactions in red maple: assessment of light transfer on carbon dioxide and water vapor exchange. Tree Physiology 24:589-597.

Berrang, P., D.F. Karnosky, and B.J. Stanton. 1985. Environmental factors affecting health in New York City. Journal of Arboriculture 11:185-189.

Boyer, L., A. Bensoussan, M. Durand, R.H. Grice, and J. Berard. 1985. Geology of Montreal, Province of Quebec, Canada. Bulletin of the Association of Engineering Geologists 22:333-394.

Brady, N.C., and R.R. Weil. 2002. The Nature and Properties of Soils. 13th Edition. Prentice Hall, Upper Saddle River, New Jersey. 960 pp.

Brazeau, A. 2003. Sable et gravier de la grande région de Montréal. Ressources minérales de la grande région de Montréal. In: D. Brisebois (Ed.). Géologie Québec, Ressources Naturelles. pp. 33-36.

Cekstere, G., O. Nikodemus, and A. Osvalde. 2008. Toxic impact of the de-icing material to street greenery in Riga, Latvia. Urban Forestry \& Urban Greening 7:207-217. 
Celestian, S.B., and C.A. Martin. 2004. Rhizosphere, surface, and air temperature patterns at parking lots in Phoenix, Arizona, U.S. Journal of Arboriculture 30:245-251.

Collins, C., M.G. Le Duc, H.A. McAllister, and R.H. Marrs. 2000. The effects of changing weather between 1967 and 1997 on the growth of Corsican pine. Arboricultural Journal 24:1-13.

Craul, P.J. 1992. Urban Soils in Landscape Design. John Wiley \& Sons, New York. 396 pp.

Craul, P.J. 1999. Urban Soils, Applications and Practices. John Wiley \& Sons, New York. 366 pp.

Cregg, B.M., and M.E. Dix. 2001. Tree moisture stress and insect damage in urban areas in relation to heat island effects. Journal of Arboriculture 27:8-17.

DeGaetano, A.T., and S.R. Hudson. 2000. Specification of soil volume and irrigation frequency for urban trees. Journal of Urban Planning and Development 126:153-165.

De Kimpe, C. and J.-L. Morel. 2000. Urban soil management: A growing concern. Soil Science, 165:31-40.

Environment Canada. 2008. McGill station mean meteorological statistics, 1971-2000. URL: http://www.climate.weather-office.ec.gc.ca/ climate_normals/results_f.html. (accessed 11/15/2008).

Flint, A.L., and S.W. Childs. 1987. Calculation of solar radiation in mountainous terrain. Agricultural and Forest Meteorology 40:233-249.

Friedman, J.H., and J.J. Meulman. 2004. Clustering objects on subsets of attributes. Journal of Royal Statistical Society B 66:815-849.

Garrec, J.-P. 1999. Urban trees and air pollution. In: M. Lemattre, P. Lemattre, and F. Lemaire (Eds.). Proceedings of International Symposium on Urban Tree Health. Acta Horticulturae 496:309-315.

Gartner, J.T., T. Treiman, and T. Frevert. 2002. Missouri urban forest: A ten-year comparison. Journal of Arboriculture 28:76-83.

Gorman, J. 2004. Residents' opinions on the value of street trees depending on tree location. Journal of Arboriculture 30:36-44.

Groot, A. 2004. A model to estimate light interception by tree crowns, applied to black spruce. Canadian Journal of Forest Research 34: 788-799.

Guo, S.W., and E.A. Thompson. 1989. Analysis of Sparse Contingency Tables: Monte-Carlo Estimation of Exact P-values. Technical report No. 187. Department of Statistics, University of Washington, Washington. 34 pp.

Guo, S.W., and E.A. Thompson. 1992. Performing the exact test of HardyWeinberg proportion of multiple alleles. Biometrics 48:361-372.

Harris, R.J., and N. Bassuk. 1993. Adaptation of trees to low-light environments: Effect on branching pattern of Fraxinus americana. Journal of Arboriculture 19:339-343.

Harris, R.J., and N. Bassuk. 1995. Effects of defoliation and antitranspirant treatments on transplant response of scarlet oak, green ash and Turkish hazelnut. Journal of Arboriculture 21:33-36.

Harris, R.W., J.R. Clark, and N.P. Matheny. 1999. Arboriculture: Integrated Management of Landscape Trees, Shrubs and Vines, 3rd Edition. Prentice-Hall Inc, New Jersey. 687 pp.

Hodge, S.J., and R. Boswell, 1993. A study of the relationship between site conditions and urban tree growth. Journal of Arboriculture 19:358-367

Hootman, R.G., P.D. Kelsey, R. Reid, and K. von der Heide-Spravka. 1994. Factors affecting accumulation of de-icing salts in soils around trees. Journal of Arboriculture 20:196-201.

Hunter, A.F., and M.J. Lechowicz. 1992. Predicting the timing of budburst in temperate trees. The Journal of Applied Ecology 29:597-604.

Jim, C.Y. 1997. Roadside trees in urban Hong Kong, Part IV: Tree growth and environmental condition. Arboricultural Journal 21:88-99.
Jutras, P. 2008. Modeling of Urban Tree Growth with Artificial Intelligence and Multivariate Statistics. Ph.D. Thesis. McGill University, Canada. 394 pp.

Jutras, P., S.O. Prasher, and P. Dutilleul. 2009. Identification of significant street tree inventory parameters using multivariate statistical analyses. Arboriculture \& Urban Forestry 35:53-62.

Kjelgren, R. 1995. Variable urban irradiance and shade acclimation in Norway maple street trees. Journal of Arboriculture 21:145-149.

Kozlowski, T.T. 1986. The impact of environmental pollution on shade trees. Journal of Arboriculture 12:29-37.

Kozlowski, T.T., and S.G. Pallardy. 1997. Physiology of Woody Plants, 2nd Edition. Academic Press (Elsevier), San Diego. 411 pp.

Legendre, P., and L. Legendre. 1998. Numerical Ecology. Developments in Environmental Modelling, 20, 2nd English Edition. Elsevier, New York. 853 pp.

Lemaire, F., and J.P. Rossignol. 1999. Stress factors related to urban soils. In: M. Lemattre, P. Lemattre, and F. Lemaire (Eds.). Proceedings of International Symposium on Urban Tree Health. Acta Horticulturae 496:347-351.

Lohr, V.I., C.H. Pearson-Mims, J. Tarnai, and D.A. Dillman. 2004. How urban residents rate and rank the benefits and problems associated with trees in cities. Journal of Arboriculture 30:28-35.

Lu, Y., Z. Gong, G. Zhang, and W. Burghhardt. 2003. Concentrations and chemical speciations of $\mathrm{Cu}, \mathrm{Zn}, \mathrm{Pb}$ and $\mathrm{Cr}$ of urban soils in Nanjing, China. Geoderma 115:101-111.

Mamy, J. 1997. De nouveaux champs de recherche agronomique. In: L.M. Rivière, (Ed.). La Plante dans la Ville: Colloque no. 84. INRA, Angers. pp. 185-187.

Miller, M. 2009. R x C: A program to perform Fisher's exact test through the use of the Metropolis algorithm. URL: http://www.marksgenetic software.net/ (accessed May 2009).

Ministère de l'Agriculture et de l'Alimentation de l'Ontario. 2003. Plantes de Pépinière et d'Ornement, Culture et Lutte Intégrée. Publication 383F, Toronto. 160 pp.

Nielsen, C.N., O. Bühler, and P. Kristoffersen. 2007. Soil water dynamics and growth of street and park trees. Arboriculture \& Urban Forestry $33: 231-245$.

Nilon, C.H. 1991. Classification of urban forests in three U.S. cities: A test of Moll's urban forest zone model. Arboricultural Journal 15:255-263.

Nowak, D.J., J.R. McBride, and R.A. Beatty. 1990. Newly planted street tree growth and mortality. Journal of Arboriculture 16:124-129.

Paludan-Miller, G., H. Saxe, L.B. Pederson, and T.B. Randrup. 2002. Differences in salt sensitivity of four deciduous tree species to soil or airborne salt. Physiologia Plantarum 114:223-230.

Paul, R. 1997. Réaction des plantes ligneuses au sel. In: L.M. Rivière (Ed.). La Plante dans la Ville: Colloque no. 84. INRA, Angers. pp. 299-308.

Percival, G.C. 2005. The use of chlorophyll fluorescence to identify chemical and environmental stress in leaf tissue of three oak (Quercus) species. Journal of Arboriculture 31:215-227.

Percival, G.C., G.A. Fraser, and S. Barnes. 2004. Soil injections of carbohydrates improve fine root growth of established urban trees. Arboricultural Journal 28:95-101.

Percival, G.C., and G.A. Fraser. 2007. The influence of commercial filmforming polymers on reducing salt spray injury in evergreen oak (Quercus ilex L.) and laurel (Prunus laurocerasus L.). Arboriculture \& Urban Forestry 33:185-192.

Prest, V.K., and J.H. Keyser. 1962. Surficial Geology and Soils of Montreal area, Quebec. Department of Public Works, City of Montreal. 70 pp. 
Raymond, M., and F. Rousset. 1995. An exact test for population differentiation. Evolution 49:1280-1283.

Smith, K.D., P.B. May, and G.M. Moore. 2001. The influence of compaction and soil strength on the establishment of four Australian landscape trees. Journal of Arboriculture 27:1-7.

Sokal, R.R., and F.J. Rohlf. 1995. Biometry: the Principles and Practice of Statistics in Biological Research. 3rd Edition. Freeman, New York. $887 \mathrm{pp}$.

StatSoft Inc. 2006. STATISTICA (Data Analysis Software System) version 7.1 and Electronic Manual. Tulsa, Oklahoma.

Systat Software Inc. 2004. SYSTAT Statistical Package, Version 11 and Electronic Manual. San Jose, California.

Watson, G.W., and E.B. Himelick. 1997. Principles and Practices of Planting Trees and Shrubs. International Society of Arboriculture, Savoy, Illinois. 200 pp.

West, L.J., and R.K.S. Hankin. 2008. Exact tests for two-way contingency tables with structural zeros. Journal of Statistical Software 28(11):1-19.

Wolf, K.L. 2004. Trees and business district preferences: a case study of Athens, Georgia, U.S. Journal of Arboriculture 30:336-346.

Zimmerman, E.M., L.G. Jull, and A.M. Shirazi. 2005. Effects of salinity and freezing on Acer platanoides, Tilia cordata, and Viburnum lantana. Journal of Environmental Horticulture 23:138-144.

Zimmerman, E.M., and L.G. Jull. 2006. Sodium chloride injury on buds of Acer platanoides, Tilia cordata, and Viburnum lantana. Arboriculture \& Urban Forestry 32:45-53.

Pierre Jutras (corresponding author)

Research Scientist, Arboriculture and Artificial Intelligence

City of Montreal, Greenspaces Department, $R \& D$

801, Brennan Street, 4th floor, Montreal

Quebec (Canada), H3C OG4

and

Adjunct Professor

Department of Bioresource Engineering, McGill University

21,111 Lakeshore Road, Ste-Anne-de-Bellevue

Quebec, (Canada), H9X 3V9

E-mail: pjutras@ville.montreal.qc.ca or

pierre.jutras@mail.mcgill.ca

\section{Shiv O. Prasher}

James McGill Professor and Chair

Department of Bioresource Engineering, McGill University,

21,111 Lakeshore Road, Ste-Anne-de-Bellevue

Quebec, (Canada), H9X 3V9

\section{Guy R. Mehuys}

Associate Professor

Department of Natural Resource Sciences, McGill University

21,111 Lakeshore Road, Ste-Anne-de-Bellevue

Quebec, (Canada), H9X 3V9

Résumé. Les arbres de rues doivent pouvoir composer avec de sévères conditions environnementales. L'identification des facteurs qui peuvent moduler leur survie et leur croissance est la clé du processus pour une gestion réussie. Pour estimer ces facteurs, des analyses de contingences ont été menées au moyens de données abiotiques colligées localement avec l'érable de Norvège (Acer platanoides L.), l'érable argenté (Acer saccharinum $\mathrm{L}$.), le micocoulier occidental (Celtis occidentalis L.), le frêne de Pennsylvanie (Fraxinus pennsylvanica Marsh.), le févier inerme (Gleditsia triacanthos L.), le tilleul à petites feuilles (Tilia cordata Mill.) et l'orme de Sibérie (Ulmus pumila L.). Des analyses de comparaison ont aussi été produites sur un ensemble de données d'espèces fusionnées ensembles. Alors que des différences nettes au niveau de la croissance ont été découvertes entre les zones commerciales et résidentielles, l'étude des espèces a démontré que des individus présentaient des tolérances écologiques particulières de par leur croissance normale ou vigoureuse face à des conditions sévères. Dans ce contexte, l'intensité de l'irradiation peut s'avérer un facteur important qui contribue à la croissance en milieu urbain. Les analyses statistiques ont mené à l'identification d'un niveau critique ( $80 \%$ d'irradiation potentielle totale) au-dessus duquel une croissance optimale a été découverte en zones commerciales. Les recherches ont aussi mis en évidence l'importance des dépôts superficiels : une croissance lente était liée à la présence de dépôts de sable/gravier. Enfin, des concentrations élevées de sel de déglaçage ont été retrouvées dans les fosses là où les arbres étaient plantés près des bordures de béton et le long des rues plus larges.

Zusammenfassung. Straßenbäume müssen mit verschiedenen harten Umweltbedingungen leben. Die Identifikation von Faktoren, die das Wachstum und Überleben beeinflussen, ist ein Schlüsselthema für erfolgreiches Management. Um diese Faktoren zu bestimmen, wurden abiotische Daten direkt am Standort von Spitzahorn (Acer platanoides L.),Silberahorn (Acer saccharinum L.), Zürgelbaum(Celtis occidentalis L.), Esche (Fraxinus pennsylvanica Marsh), Gleditschie (Gleditsia triacanthos L.), Winterlinde (Tilia cordata Mill.), und Sibirischer Ulme (Ulmus pumila L.) erhoben und einer Kontingenz-Analyse unterzogen. Vergleichbare Analysen wurden auch für einen Standort mit gemischten Arten durchgeführt. Wo scharf differenziertes Wachstum zwischen industriellen Standorten und Siedlungsbereichen vorgefunden wurde, zeigten die untersuchten Arten doch eine ökologische Toleranz, wo einzelne Exemplare unter schweren Standortbedingungen normales oder vitales Wachstum zeigten. In dieser Situation könnte die Strahlungsintensität ein wichtiger Faktor für das Baumwachstums sein. Statistische Analysen führten zu der Identifikation eines Grenzwertes (80\% der total möglichen Einstrahlung), über dem optimales Wachstum an industriellen Standorten gefunden wurde. Die Untersuchungsergebnisse haben auch die Bedeutung von der Untergrundbeschaffenheit zum Vorschein gebracht: langsame Wachstumsraten waren verbunden mit Sand/Schotter-Untergrund. Zum Schluss, höhere Salzkonzentrationen wurden in Pflanzgruben gefunden, wo die Bäume näher an die Straße gepflanzt wurden oder entlang breiterer Straßen.

Resumen. Los árboles urbanos deben enfrentarse con severas condiciones ambientales; la identificación de los factores que modelan su supervivencia y crecimiento es un proceso clave para el manejo exitoso. Para estimar estos factores, se llevaron a cabo análisis usando datos abióticos colectados localmente para árboles de maple Norway (Acer platanoides L.), maple plateado (Acer saccharinum L.), almez (Celtis occidentalis L.), fresno (Fraxinus pennsylvanica Marsh.), acacia (Gleditsia triacanthos L.), tilo (Tilia cordata Mill.) y olmo Siberiano (Ulmus pumila L.). También, fueron realizados análisis comparativos en paquete mezclado de todas las especies. Mientras fueron encontrados leves crecimientos diferenciales entre zonas comerciales y áreas residenciales, los estudios de especies demostraron tolerancia ecológica como individuos normales o creciendo vigorosamente en condiciones severas. En esta situación, una intensidad amplia de irradiación puede ser un factor importante que contribuya al crecimiento del árbol urbano. El análisis estadístico permite la identificación de un nivel umbral $(80 \%$ de irradiación potencial total) arriba del cual el crecimiento óptimo fue encontrado en zonas comerciales. Los resultados de la investigación también traen la importancia de los depósitos superficiales subyacentes: tasas bajas de crecimiento estuvieron ligadas a la presencia de depósitos de arena/ grava. Finalmente, fueron encontradas altas concentraciones de sales de deshielo en pozos de árboles trasplantados cerca a las guarniciones y en calles más amplias. 